\title{
Impact of Micro Finance Institutes (MFI's) on the Growth of Small and Medium Enterprises (SMEs) in Khyber Pakhtunkhwa
}

\author{
SYED UZAIR \\ MS-Management Sciences, CECOS University of IT \& Emerging Sciences \\ uzairkkk@hotmail.com \\ DR. FAHAD KHAN AFRIDI \\ Assistant Professor/Chairman Department of Management Sciences \\ CECOS University of IT \& Emerging Sciences \\ fafridi449@gmail.com \\ DR. MUHAMMAD ADIL \\ Assistant Professor/Head, Department of Management Sciences \\ Bacha Khan University, Charsaddah \\ Madilkhan3@hotmail.com
}

\begin{abstract}
Economic stability is very necessary for the development of economy a country. For this purpose industrialization plays a positive role in fulfilling this achievement. The trend of borrowing from Micro Finance Institutions increases day by day as business activities takes place. Also from political stability Foreign Direct Investment takes place resulting in boosting and competitive environment for domestic investors. MFIs serving in all cities of Pakistan focus on enhancing business activities on domestic level. Each and every bank has its own microfinance institution departments focusing mainly on fulfilling the access to finance through some easy steps for starting new ventures. From past some years Pakistan is facing a lot different situations in country like Political Instability, Terrorism and Unemployment. Now in this situation there is lack of foreign investment in our country. Meanwhile, Domestic Level Small \& Medium Enterprises faces a lot of challenges while financing their own SMEs. State bank of Pakistan introduces Business Support Fund through which every bank has to facilitate investors with loans to increase new ventures startup which in turns can help out the economy. Trend of MFIs and SMEs had increase in Khyber Pakhtunkhwa as well like Faisalabad, Karachi and Lahore so do demand for credit investment increases resulting in MFIs with new ideas and proposals.
\end{abstract}

Key Words: Micro Finance Institute, SMEs, Direct Investment, Khyber Pakhtunkhuwa

\section{Introduction}

\subsection{Background of the Study}

Normally for the development of the country economic situation takes place a vital role in building the country position in all aspects to compete with other neighbor countries and to sustain his position. Pakistan is a developing economy and there are many challenges for Pakistan to compete with like unemployment, lack of education, unskilled workers, poor industry, and lack of proper utilization of resources now for all this we 
need to do something to conduct researches to fulfill our problems. While on other side there is lack of SME's in our country but they plays very positive role in building of the economy. Employment and Assets made SME's position (State Bank Of Pakistan) like in Europe SME's is a firm having not more than 250 employees, on the other side in US it is defined as 500 employees working in firm or an organization (European Commission Report, 2005). SME's are sub-divided into three forms like Micro Enterprises, Small Enterprises and Medium Enterprises. Micro Enterprises have employees working not more than 10; Small Enterprises consist of employees range from 10 to 35while Medium Enterprises consists of 36 to 99 employees working. (Small \& Medium Enterprises Development Authority SMEDA). Pakistan government had introduced the SME's Business Support Fund (BSF) to improve the performance of SME's in country. Indonesia plays a huge role in SME's acting $60 \%$ to their economy and $97 \%$ of the workforce in Indonesia is doing job in SME's (Indonesia, Central Bureau of Statistics, 2011). Economic crisis of 1997 in their country do not harm SME's and they sustain their position as well as production in the market due to the reason that they are neutral and they are free without the interruption of government and its policies. For the enhancement of the performance of different SME's several factors must keep in mind affecting the SME's like entrepreneurial aspect plays a huge role in the developing process of the economy like the internal motivation for doing something good for the business, showing some self-efficacy towards business, self-management and optimism, competence of human resources is also important by having skills, ability and knowledge regarding business. Same is the case with the innovative factor by creating something new different from other products of business and use of new technological aspects.

Sustainability factor is playing very important role because to capture the market is not an easy job due to the reason that growth and profitability is the key to success which is difficult job to maintain in the market having competitors edge (Bayercelik et al., 2014; Anggadwita and Mustafid, 2014; Jasra et al., 2011). Similarly for all this process every business needs some kind of finances through the help of financial institutions like different kinds of banks which are playing a huge role in lending to SME's (Mbugua el al., 2013; Johnson Yeboah et al., 2014; Khan, 2015). State Bank of Pakistan is leading this mission by implementing this factor on commercial banks like there are different packages offering by different banks in loan perspective. SME Bank Limited is providing Smart Loans, Asset Finance \& Running Finance for SME's. MFI's are not that much popular than other commercial banks but they are performing well to provide loans to poor people to start business setup. These institutions include Apna Bank Limited, Finca Microfinance Bank Limited, Khushhali Microfinance Bank, NRSP Microfinance Bank Limited and Pak Oman Microfinance Bank Limited (Ahmad \& Salam, 2010; Hamid \& Ullah, 2006). Other large size banks are also offering loans for SME's like NIB Bank Limited is offering Small business Loans \& Salaam Business Loans. Citi Bank is providing Running Finance for SME's \& Term Loans for SME's. Standard Chartered Bank Limited is providing loans for different sectors like for textile weavers it is Tana Bana, for textile dyers Rang Hi Rang, for agriculture sector it is Kissan Card and Agri Deal. United Bank Limited is offering Rice Paddy Advances, Cotton Ginner Advances, Credit facilities against Liquid Securities and Running Finance for SME's Schemes. Bank Alfalah is offering Alfalah Karobar Finance, Alfalah Malkiat Finance \& Alfalah 
Quick Finance. Bank of Punjab is offering Lady Entrepreneur Financing Scheme, Karobar Bahraho Scheme, Franchise Financing Scheme, Atlas Honda Dealer Financing Scheme \& Millat Tractors Dealers Financing Scheme. Atlas Bank limited is offering Agri Line (Hamid \&Ullah, 2006; Ahmad \& Salam, 2010). This research wants to investigate the impact of MFI's lending on the growth of SME's in Pakistan. The literature is deficient in Impact of Micro Finance Institutes' (MFI's) Lending's on the Growth of SME's in Khyber Pakhtunkhwa and this study would fill this gap. This study would tries to fill that gap in the existing literature which can help in the growth of economy.

\subsection{Problem Statement}

According to previous researchers KPK is developing economy \& is lacking support of the literature. KPK is $3^{\text {rd }}$ largest province but due to war \& terror business/industry transfer from this province to another. SME's has not tremendous growth as compared to Karachi, Faisalabad \& Lahore. So, it is need of the day to search the impact of growth on SME's. (Ahmad, F. \& Salam, A., 2010; Hamid \& Ullah, 2006; Syed Kamran Shirazi et al., 2013; Muhammad Asif Khan et al, 2011).

\subsection{Research Questions}

1. Do MFI's play a positive role in the economic growth of KPK?

2. What are the major obstacles which are coming in the way to finance SME's?

3. Is SME's provided greater provision of employment?

\subsection{Objective of the Study}

1. To check difficulties which are coming in the ways of business in KPK

2. To check the role of MFI's in the provision of the SME's.

\subsection{Significance of Research}

This research may provide an opportunity of additional literature to the future researches additionally the role of SMEs if clearly understood so the young generation (university graduates) may opt for own business instead of searching jobs in other organizations.

\subsubsection{Lending to Individuals by MFI's}

Individual lending is the type of lending in which loan is provided to the customer and for that a high amount of collateral is paid by the single owner of the SME so chances of default and burden are on only one person.

\subsubsection{Lending to Groups by MFI's}

Group lending is the type of lending in which loan is provided in groups that technique was first used by Grameen bank in Bangladesh and was very successful due to the reason that collateral on the individual are small compared to single owner and they can easily pay it.

\subsubsection{Collateral towards MFI's}

Collateral is a type of assurance that if the owner fails then he has another source from which he can recover repayment to lender. This is a basic variable which is used everywhere in the world as for repayment purpose like it contains building, land and cash. Most of the customers faced challenges while borrowing from banks due to high amount of collateral and that is the bigger reason that group lending technique is much more popular compared to individual lending.

\subsubsection{Accessibility of Credit by MFI's}

The demand for loans increases day by day as businesses are unable to operate without expanding their business according to market needs for which they goes towards loans 
from MFIs but there are some strict policies through which the process are made difficult for poor SMEs to finance themselves like documentation cost is high as well as process for availing loans are lengthy.

\subsubsection{Profitability}

SMEs cannot survive without profitability of the business. Profitability of the business are dependent on many different factors including group lending, collateral, individual lending as well as access to finance. Growth and development of the country are measured and judge by profitability of the SMEs so this variable is very necessary for the economic growth of a country which are totally reliable on these figures.

\section{Literature Review}

\subsection{Literature Analysis}

The importance of SME's has been revealed by many researchers as it had played a vital role in the Economic Crisis of Indonesia in 1997 in which SME's are not affected by the crisis as they are not under government regulatory and even in that situation they survive and sustain their position in the economy (Anggadwita \& Mustafid, 2014). Also (Tambunan, 2006) argued in his research that SME's playing huge role in giving employment and source of income. The importance of the performance of SME's had been suggested by (Ahmad, 2007) that researchers should conduct researches regarding environmental and internal factors which influence performance. Pakistan has many problems as fear of competition and performance in global market of SME's is very big challenge (Akhtar et al, 2011). Collateral Issue is the reason due to which SME's cannot afford debt financing revealed by researcher in a study conducted in Somalia (Siyad, 2013). For the success of a business there are several factors playing important role like skills, education and characteristics an entrepreneurial have (Ullah et al, 2011). Furthermore there study reveals that Pakistan has lack of training and education due to which most of the SME's fails on their start up as they don't have any professional ideas of the business techniques. Access to finance is very necessary for the establishment of a business which is the main problem SME's are facing in Ghana (Abor \& Biekpe, 2009). Business Enterprise \& Regulatory Reform (BERR) in United Kingdom focuses on the development of business enterprises for the development of the economy and business activity (Deakins \& Freel, 2009). Due to lack of repayment capacity of SME's they don't go towards lending process revealed in the study of Pakistani researchers (Hamid \& Ullah, 2006). Assessment of potential strong SME's can get loan while weak remains with no capital in hand (Johnson Yeboah et al., 2014).

Finances for Small \& Medium Enterprises increased 27\% in 2016-17 according to State Bank of Pakistan (DAWN, 2017). Large businesses are accounted 54\% in the economy while SME's are accounted 19\% only due to lack of business financial sources (Syed Kamran Shirazi et al., 2013). SMEDA in 2001 confirmed that taking credit from banks takes up to 10 months delay process and no doubt this delay is enhanced due to the rules $\&$ policies of the State Bank of Pakistan. Innovation of a business is dependent on financial factor like innovation takes place when there is capacity which in turns linked with the resources of a business from which many problems can solved (Bayercelik et al., 2014). Crowd funding is also a source for raising finance as an alternative source by starting some creative type projects, money collects in this process are small amount but from large amount of people (Eniolaa \& Entebang, 2015). Collateral Security 
requirement has been recorded $41.20 \%$ in a study conducted in Ghana (Johnson Yeboah et al., 2014). Collateral is an important factor while accessing debt finance (Bougheas et al, 2005). A study conducted in Nigeria reveals that up to $70 \%$ they finance their business from internal funds and only $1 \%$ goes towards debt financing. Group lending concept was first introduced in Bangladesh by the Grameen Bank for solving loan problems of poor borrowers and was than very successful helping poor borrowers for loans approval in groups (Tutlani, 2016). Group lending is a way of financing in which credit is provided to the clients without having any difficult collateral issue as they have to work hard for the repayment of credit due to the reason that they might not able for future credit (Natarajan, 2004; Gine \& Karlan, 2010; Madajewicz, 2003). The advantage of lending in group also leads towards the failure of any of the group member to repay (Besley and Coate, 1995). Group lending is more effective than individual lending reveals in a study conducted in Kenya (Kodongo \& Kiendi, 2013). Individual Lending option can be used but by having collateral which is used as a second source of credit repayment. Equipment's, Building or Inventory can be used as a source for recovery (Siyad, 2013).

The process of group lending is very time consuming while for individual lending it is easy to handle documentation reveals in the study conducted in Kenya (Maria, 2009; Gine \& Karlan, 2010; Warui, 2012).Study conducted by (Ogbuabor et al., 2013) finds that SME's of Nigeria are going towards development and for future opportunities access to finance provide base for developing of their business. Human, financial and physical are playing its own role in sustaining the life cycle of the SME's.(Fatoki, 2014). Financing of business is one of the big issues revealed in the study of (Pang, 2006) due to which $80 \%$ of new ventures fails having lack of capital for competing in market. The importance of the Financial Resources of a business and access to banks has been revealed in the studies of (Jasra et al., 2011) as the most important factors in the determinant of success. Collateral issue is the big problem faced by SME's as they don't have any collateral demanded by MFI's at the time of borrowing (Quartey et al, 2017; Issac Quaye et al, 2014; Woldie et al, 2012). Accessibility of credit is the basic step for the loan process which is very good in Africa as they provide loans without having charges and without any guarantees (Issac Quaye et al, 2014).For the regional growth US government introduces guaranteed loans for new ventures due to the reason of the lack of collateral problem clients faced while borrowing from financial institutions (Lee Y. S., 2018; Murrins \& Toro, 2017). Researcher argues that SMEs plays a positive role in reduction of poverty and availability of employment (Tombo et al, 2008). The importance of SMEs as a tool for promotion and economic growth are revealed from the study conducted by (Kachembere, 2011). The role and importance of SMEs are very huge in increasing income and reducing unemployment (Alhassan \& Hoedoafia, 2016).

Due to cultural, social, unskilled and inexperienced women's entrepreneurs fail to run SME properly while availing loans from MFI (Duvendack et al, 2011). Females can run basically household enterprises reviled in a study conducted in Ghana (Abor \& Biekpe, 2006). Research conducted by (Roomi \& Parrot, 2008) also reveled in their study that women's to have less opportunities compared to men's due to cultural and social problems. Access to finance plays a positive role in poverty reduction and creation of jobs (Idowu, 2010). Study conducted in Kenya by (Munyao, 2012) finds out that loan from MFIs helps in expanding business in terms of profitability, increase in employees 
numbers, services promotion as well as increase in assets of the business. On the other side it is observed in a study that credit from MFIs does not lead to development of market share of SME and not helps in the development of assets (Atandi \& Wabwoba, 2013). Business requires short term financing as well as long term financing and for this availability of cash is necessary (Sorensen, 2012). Development of a business can be identified either by investment in a business or by sales figure (Khan \& Jain, 2012). There found a positive relationship between SMEs and MFIs in Kenya (Cooper, 2012). The importance of profitability is discussed in the study conducted by (Sanchez et al, 2011) that if interest rate is high profitability is less as it is find out about its ratio formula. Rejection of loans from microfinance institutions are also due to the reasons that entrepreneurs who want to avail loans did not even prepare a business plan for which they faced difficulties from microfinance institutions resulting in failing of availing loans from them (Ahinful, 2012; Awuah \& Addaney, 2016).

For expansion of business a large amount of cash is required which is impossible for the entrepreneurs of SMEs to fulfill easily and no doubt MFIs also have known about the how much loans do SMEs avails from them so they also give them priority to expand their business by giving them higher amount of loans (Addaney et al, 2016). However SMEs plays very difficulties while accessing to loans in Ghana (Adomako \& Anash, 2012). Asian crisis of 1998 ruined the economy of Indonesia completely for which they even change their banking structure as a result they change their banking structure from corporate to microfinance (Ghalib, 2017). Microfinance concept takes boost when Muhammad Yunus introduces the concept of microfinance in Grameen bank for supporting poor people especially women and availing them with short term loans (Mersland \& Strom, 2016). The benefits and positive role of MFIs as for boosting of economic development of a country is noticed in the study of $\mathrm{PhD}$ professor in his study (Nuwagaba, 2015). Change from social service loan towards business loan of MFIs are been discussed in the study of (Cedric, 2012). Pakistan had done a positive achievement increasing number of SMEs as 3.2 million and availability of employment as $78 \%$ as well as contribution to economy as 30\% (Hussain, Farook \& Akhtar, 2012). Problem faced by Kenyan enterprises while accessing loans like high amount of interest, short term time for paying and limited amount are discussed in the research of Kenyan researcher (Mwobobia, 2012; Omondi \& Jagongo, 2018). Ghana MFIs plays a positive role in making access to loans easy for small and medium size enterprises which is being discussed in the regression model of the study (Ahiawodzi \& Adede, 2012).

\subsection{Theoretical Framework}

Theoretical concept of this research can be followed by different theories by different theorists as for the running business on the path of success requires more capital to enhance business and for employer go towards debt financing.

\subsubsection{Pecking Order Theory}

Myers \& Majluf (1984) theory states that financing of a business takes place from three sources, preferable source of finance is from internal funding from business if not possible second comes from debt financing i.e. borrowing from banks and micro financial institutions and the last option which is not much preferable as it involves external people as an employer of the business while issue shares by using equity financing method. (Kira \& He, 2012; Johnson Yeboah et al., 2014; Fatoki \& Asah, 2011) 


\subsubsection{Theory of Stage Development}

Churchill \& Lewis (1983) theory states that there are five stages of growth of a business including existence, survival, success, take-off and resource maturity. Firsts there comes existence of a business that when it exists business activities takes place, Seconds comes survival of a business in market which is also very necessary to maintain its position well, Third comes the success of a business by properly managing get with this reward, Fourth comes take-off in which business captures market by beating its competitors and then last comes resource maturity which is the peak stage of a business in which sales of a business are on peak having professional staff and financial resources for the business decisions as well as for planning. (Mbugua el al., 2013; Siyad, 2013).

\subsubsection{Transaction Cost Theory}

Ronald (1937) theory is about the existence of a business which tries to explain why companies expand \& use external source of funding. Also this theory states that a business can expand \& enhance its performance by having performing cheaper in market. (Siyad, 2013)

\subsubsection{Passive Learning Model (PML) Theory}

Jovanic (1982) theory is about the potential growth \& profitability of a business while entering market a business is unaware of its potential growth but after entering market it starts to learn \& then decides to expand or to quit the business. (James K. Mbugua et al., 2013; Siyad, 2013)

\subsection{Hypotheses}

Hypotheses of this research are as follow

- $\quad \mathbf{H}_{1}$ : Lending to Individuals by MFI's has a positive impact on the growth of SME's.

- $\quad \mathbf{H}_{2}$ : Lending to Groups by MFI's has a positive impact on the growth of SME's.

- $\quad \mathbf{H}_{3}$ : Collateral towards MFI's has a positive impact on the growth of SME's.

- $\quad \mathbf{H}_{4}$ : Accessibility of Credit by MFI's has a positive impact on the growth of SME's.

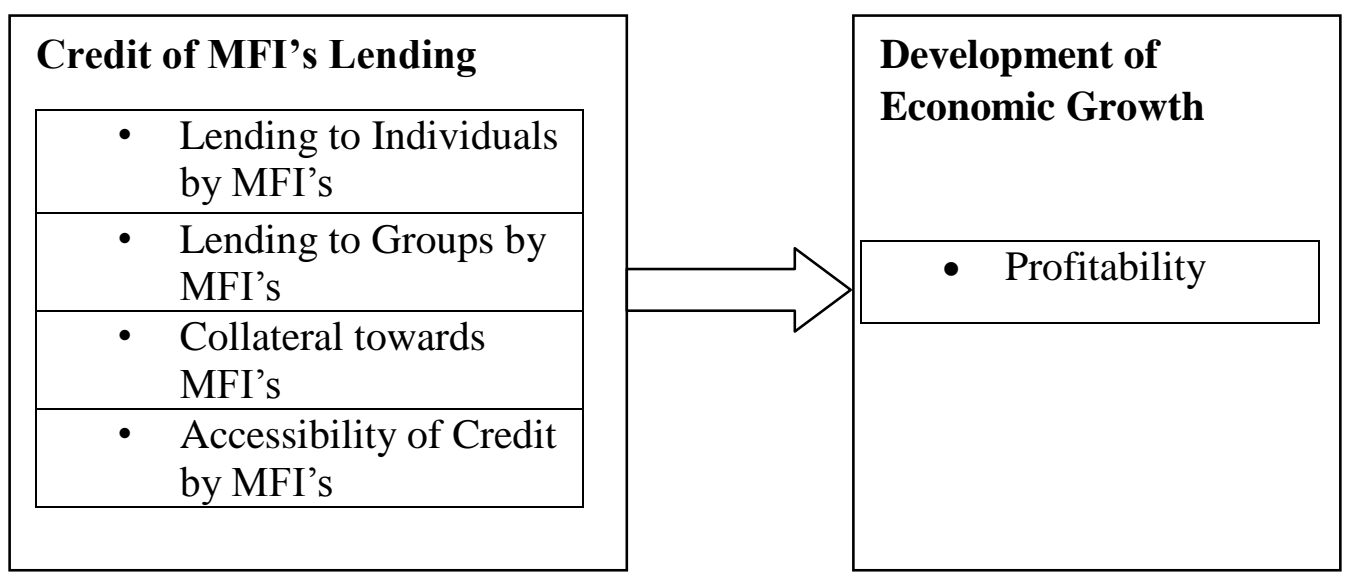

Figure 1: Conceptual Framework

\section{Research Methodology}

\subsection{Research Philosophy}

This research study was based on Positivism philosophy as this type of philosophy depends upon quantifiable observations which can analyze statistically and the approach 
used was deductive as it is concerned with hypotheses on the basis of theories existing for research.

\subsection{Research Nature}

Nature of this research was quantitative and investigative method was used for the collection of primary data from the owners of SMEs through adoptive questions.

\subsection{Research Population}

Population for this research was 135 SME's who had avail financial support from MFI's in Khyber Pakhtunkhwa. These different SMEs includes different sectors like manufacturing sector which includes Ceramics, Sanitary, Furniture, Plastic, Beverages and Addible Oil while service sector includes Transportation, Education and Insurance.

\subsection{Sample Frame}

SMEs operating in different regions of Khyber Pakhtunkhwa who avail loan from MFIs are of different sectors like Ceramics, Sanitary, Furniture, Plastic, Beverages, and Addible Oil while service sector includes Transportation, Education and Insurance. These SMEs are

1. Zamoung Textile Company

2. Ghareeb Shah Trading

3. Amar Construction Company

4. Utman Group

5. Qazi Corporation

6. Libra-PBT

7. Afridi United Goods Transport Company

8. Alpha Pipe Industries

9. Pak Traders

10. Taj Wood Flour Mills

11. Himmel Tech

12. Digital Paradise

13. DODO Services

14. National Electric Services \& Consultants

15. Ali Bhai \& Son's

16. SurgiPlast

17. Mirza Brother Feed

18. E-Digital Pakistan

19. IT Spurt Pvt Ltd

20. Deans Industries

21. Al-Hafiz Crystoplast

22. Rafiq Sweets

23. GIT Alliance

24. Scholars Education Academy

25. Megeasshop

26. SS Polypropylene Pvt Ltd

27. FEnD Consultants

28. Techno Wind Solutions Pvt Ltd

29. Frontier Group of Companies

30. Hafiz Gemstones \& Minerals 
31. Sohail Vegetable Ghee Mill

32. Sarhad Traders

33. Mazhar Enterprises

34. Buraq Network Pvt Ltd

35. Zahaq Associates Pvt Ltd

36. Frontier Telecom

37. Haji Aurangzeb \& Son's

38. Khanial Builders

39. Premier Formica Industry

40. Gohar Publishers

41. Zeb Associates

42. Pak Accumulators

43. Xcube Innovations

44. Chef Int'L

45. IT Charisma

46. Mardwal Engineerings

47. Arshad Corporation

48. Barakat Rice Mills

49. Sadiq Feeds

50. Miran Shah Petroleum

51. Khawar Traders

52. Sarhad Woolen Mills

53. Sajjad Sweets \& Bakers

54. Nexus Pharma

55. Coral Enterprises

56. Z.S Logistics

57. Moon Enterprises

58. Pharmagen Limited

59. Hira Terry Mills

60. Qaiser Electronics

61. Agro Zat International

62. Liberty Power Tech

63. Kafi Commodities

64. UCC Pvt

65. Rayyan Autos

66. J.A.S International Enterprises

67. Rafiq Pvt

68. Tauqir Brothers

69. Master Wool Spinners

70. Ashraf Dad Khan

71. Ali Akbar Enterprises

72. Ever Bright Builders

73. Hira Enterprises

74. Innovision Technology

75. Al Latif Chemist 
76. IT Spurt Pvt Ltd

77. Sana Trade Corporation

78. Rtg-Int

79. M/S Ihsan Sons

80. Nile Trading

81. Mayani Poly Packages

82. Malik Associates

\subsubsection{Sample Size}

By using Solvin's formula for the calculation of sample size

$n=\frac{N}{1+N e^{\wedge} 2}$

$\mathrm{n}=$ Sample size

$\mathrm{N}=$ Population

$\mathrm{e}=$ Margin of error which is $5 \%$ of the total population

Sample of 100 SME's will be taken for further analysis.

\subsubsection{Sampling Technique}

Random Sampling is the basic sampling technique where a group of subjects (sample) is taken from a larger group (population). Each individual is chosen entirely by chance and each member of the population has an equal chance of being included in the sample.

\subsection{Unit of Analysis}

Primary data will be collected by distributing questionnaires among the organizers of SME's who have avail loans.

\subsection{Research Strategy}

Convenience data was collected from small business entrepreneurs supported by MFIs for running of their business.

\subsection{Data Collection Procedure}

This research consists of Primary data and time horizon for the data is Cross sectional. Furthermore Lickert scale will be used for the collection of data from respondents which is from 5 to 1 (5 is completely agree and 1 is completely agree) as well as descriptive techniques will be used. Scale was adopted from the previous study conducted by research scholar while some changes in scale are made with new modification in questions to gain more relevant results. Cronbach's Alpha for the reliability tests of the lickert scale questions is 0.807

\subsection{Data Analysis Technique}

SPSS will be used for the analysis of data. Simple Linear Regression Model will be used to show dependent $(\mathrm{Y})$ and independent $(\mathrm{X})$ variables of the study for which equation is

$Y=\alpha_{0}+\beta_{1} X_{1}+\beta_{2} X_{2}+\beta_{3} X_{3}+\beta_{4} X_{4}+\varepsilon$

Where

$\mathrm{Y}=$ Development of Economic Growth (Profitability)

$\mathrm{X} 1=$ Lending to Individuals by MFI's

$\mathrm{X} 2$ = Lending of MFI's to Group

$\mathrm{X} 3=$ Collateral towards MFI's

X4 = Accessibility of Credit by MFIs

$\beta=$ Independent variables coefficient 
$\alpha_{0}=\mathrm{Y}$ value when all other variables value is zero

$\varepsilon=$ Error term

4. Results and Discussion

4.1. Introduction

Analysis and data presentation was covered in this chapter. Objective of this study was to analyze the impact of MFIs on the growth of SMEs in Khyber Pakhtunkhwa. SPSS Statistics 19 software was used for the interpretation of data.

Table 1: Response Rate

\begin{tabular}{lrr}
\hline Questionnaires & Frequency & Percentage \\
\hline Returned & 82 & 0.82 \\
Unreturned & 18 & 0.18 \\
Distributed & 100 & 100.0 \\
\hline
\end{tabular}

Source: Research Findings

Focus of this study was on the SMEs in Khyber Pakhtunkhwa. In the first part of the study descriptive statistics was used and later econometrics model was use for analysis of data. Solvin's formula was used for the collection of data for which response rate of the study is 82 out of 100 distributed questionnaires.

$n=\frac{N}{1+\mathrm{Ne}^{\wedge} 2}$

$\mathrm{n}=$ Sample size

$\mathrm{N}=$ Population

$\mathrm{e}=$ Margin of error which is $5 \%$ of the total population

4.3. Descriptive Statistics

In this portion of the study descriptive statistics of respondent's response was studied through pie charts, bars and frequency tables. These pie charts, graphs and tables will be further explained that how much each and every variable is performing its role either positive or negative. These graphs, charts and tables will be the data and questionnaires collected from the managers of SMEs through which each and every point should be made clear.

\subsubsection{Age of the Responses}

The responses age was divided into four categories i.e. 18-21 for the first category, 22-26 for the second category, 27-30 for the third category and 31-above for the fourth category of age. For the age category of 18-21 4\% was the respondent age, for the age category of $22-268 \%$ was the respondent age, for the age category of 27-30 26\% was the respondent age and for 30 -above $62 \%$ was the respondent age. Most of the respondent age was above 30 due to the reason that business requires a lot of experience which is a difficult task for non experience entrepreneur to run their business while on the other hand above 30 year owners do have know how about market and can stable their self in market, 


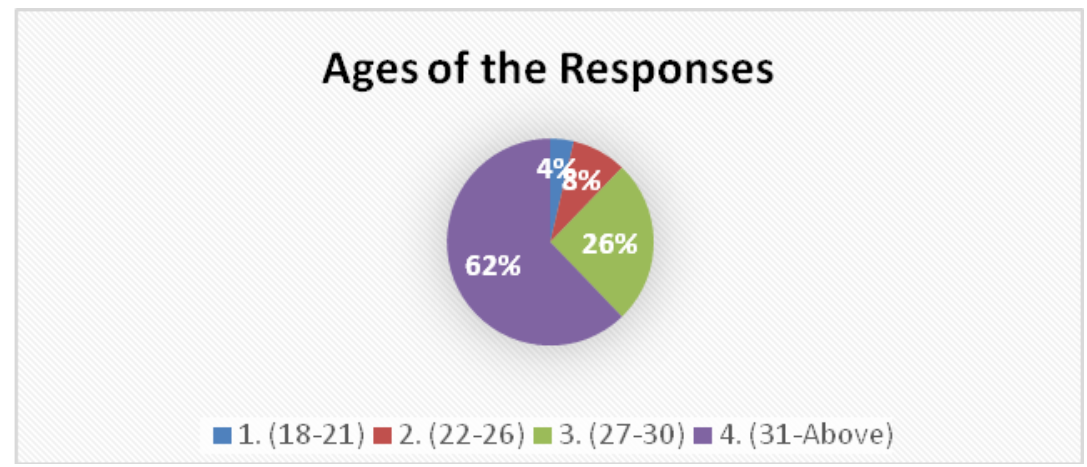

Figure 2: Age of the Responses

\subsubsection{Gender Wise}

Source: Research Findings

The above figure shows that $30 \%$ of females avails the loans from Micro Finance Institutions in Khyber Pakhtunkhwa while $70 \%$ of the males avails the loans. The percentage of starting enterprises and opportunities for it is more for man then that of women. The chart simply shows dominancy of men's over women's due to the reason that there are a lot of problems faced by women's while doing business like training, skills, cultural aspect and market information which makes men's more dominant over women's to do business in market very well.

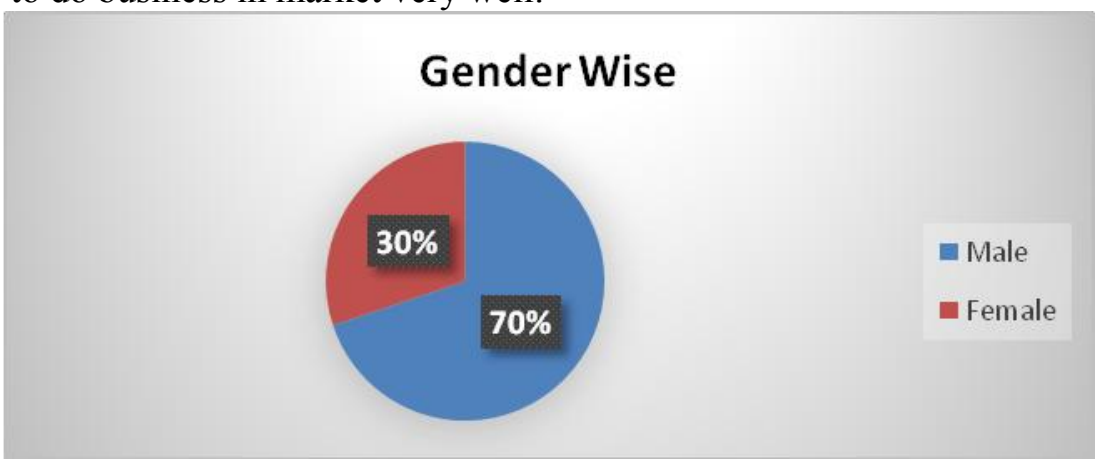

Figure 3: Gender Wise

Source: Research Findings

\subsubsection{Nature of Enterprises}

Out of 83 respondents 32 were from manufacturing sector ${ }^{1}, 15$ were from service sector ${ }^{2}$, 14 were from construction sector, 5 were from cloth sector, 3 were from cosmetics sector, 7 were from electronics sector, 1 from books and 6 from shoes. From below chart it is confirmed that most of the SMEs involve in manufacturing then service as well as construction sector. Most of the SMEs engaged in manufacturing like large amount of data were collected from manufacturing sector especially pharmaceutical sector.

\footnotetext{
${ }^{1}$ Ceramics, Sanitary, Furniture, Plastic, Beverages, Addible Oil

${ }^{2}$ Transportation, Insurance, Education 


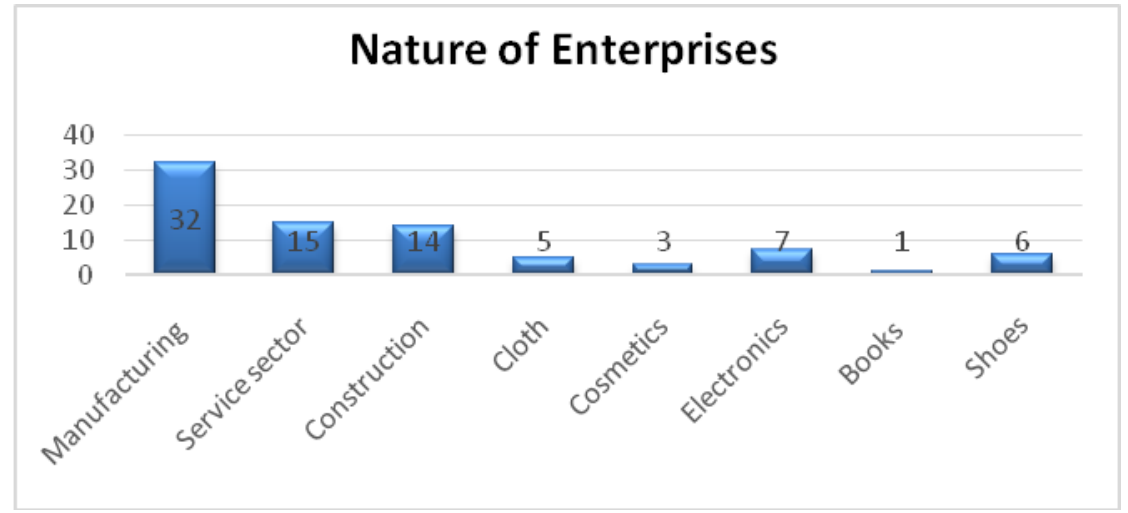

Figure 4: Nature of Enterprises

\subsubsection{Sources of Business Capital}

Source: Research Findings

26 of the respondents used personal savings as their source of business capital, 17 of the respondent used family as their source, 38 of the respondents used micro finance institutions as their source while 1 of the respondent used partnership as their source. By comparing these four sources of business capital it is confirmed that most of the SMEs used MFIs for their business capital while personal saving is also used as their source. From this graph it is also cleared that customers mostly relay on loans from MFIs as they don't have any other source for their business expansion.

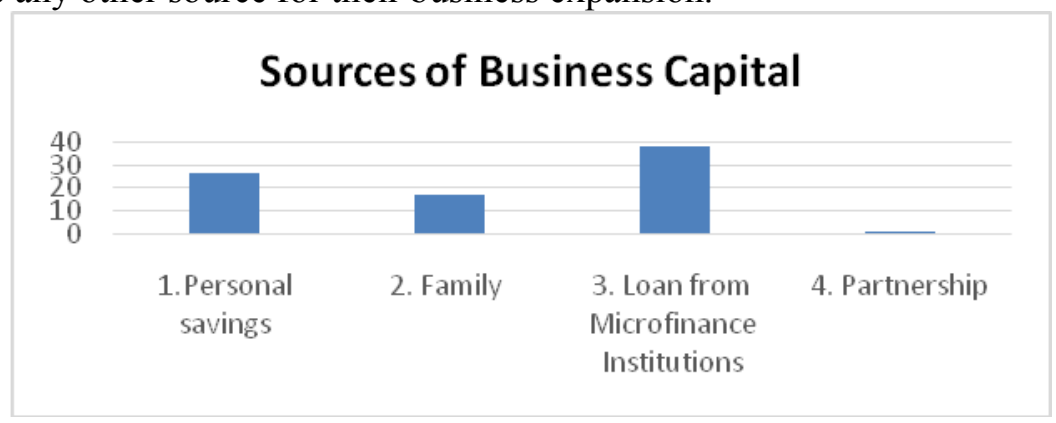

Figure 5: Sources of Business Capital

\subsubsection{Collateral towards SMEs}

Source: Research Findings

In this analysis it was confirmed that $65 \%$ of respondents were unable to afford collateral requested by MFIs while lending, However $35 \%$ of the respondents was able to afford collateral easily. Collateral is the first thing requested by MFIs while lending and from this chart it is confirmed that entrepreneurs faced challenges while borrowing money from MFIs and the major reason is collateral. 


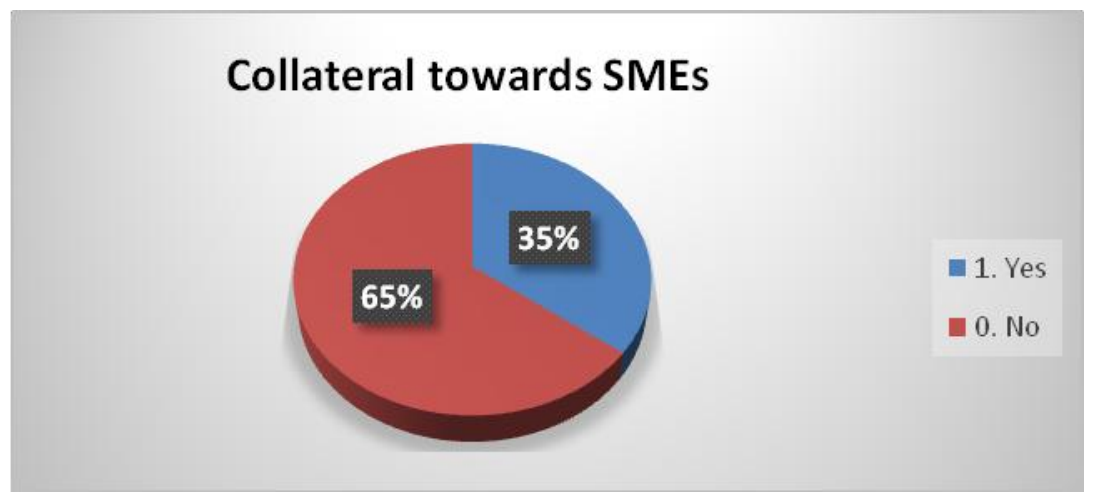

Figure 6: Collateral towards SMEs

\subsubsection{Challenges from MFIs}

Source: Research Findings

$40 \%$ of the respondents do not faced different challenges from MFIs while borrowing while $60 \%$ of the respondents faced challenges from MFIs. These challenges include long time documentation process for loans, high amount of collateral and bank strict policies. For removing these challenges up to some extent MFIs requires to create research and development department to identify challenges faced by customers to resolve it up to some good extent.

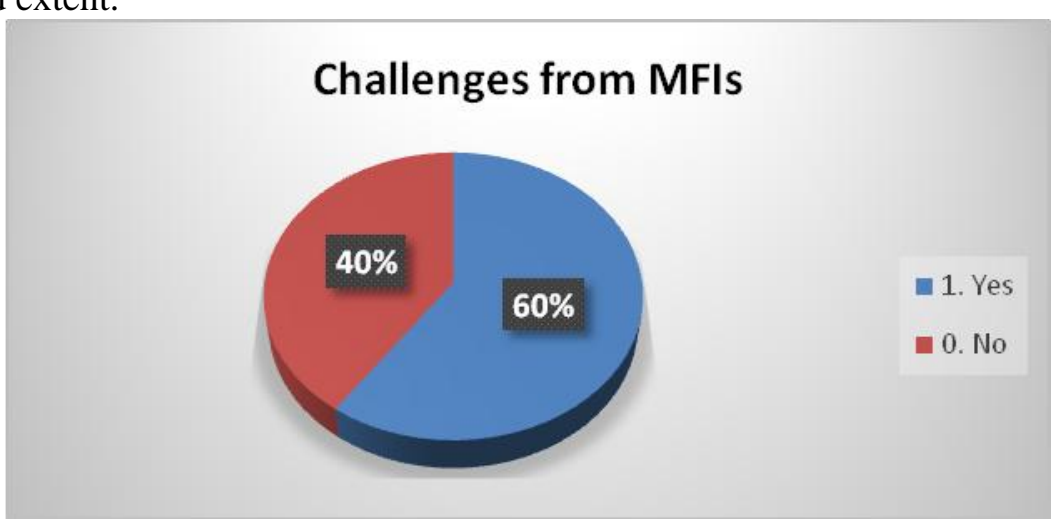

Figure 7: Challenges from MFIs

Source: Research Findings

\subsubsection{Engagement of Employee}

Number of employees working in SMEs was 1-49 according to 63 respondents while 5099 employees were working according to 19 respondents. This graph shows that from SMEs there is benefit of employment of poor people as well as qualified people which can easily get jobs in SMEs as an administrative or as marketers. Number of employee figure increases day by day as the SMEs enhance its operation in different regions resulting in economic development. 


\section{Engagement of Employee}

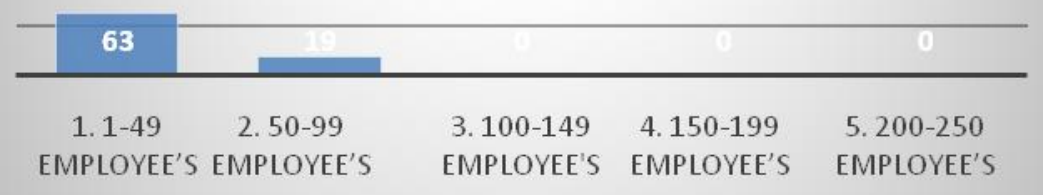

Figure 8: Engagement of Employee

Source: Research Findings

Table 2: Descriptive Statistics on SMEs Growth and MFIs Lending

\begin{tabular}{|c|c|c|c|}
\hline Statement & $\mathbf{N}$ & Mean & SD \\
\hline MFIs loans increases profitability of your SMEs & 82 & 3.91 & 1.021 \\
\hline MFIs always required collateral before they give loan to SMEs & 82 & 4.43 & .648 \\
\hline MFIs provide access to finance towards SMEs easily & 82 & 3.51 & 1.021 \\
\hline MFIs provide Individual lending to SMEs & 82 & 3.21 & 1.039 \\
\hline MFIs provide Group lending to SMEs & 82 & 4.30 & 1.193 \\
\hline MFIs increases support of new entrepreneurs starting business & 82 & 4.52 & .997 \\
\hline $\begin{array}{l}\text { MFIs don't support poor entrepreneurs who want to expand } \\
\text { their business with a loan }\end{array}$ & 82 & 4.00 & 1.176 \\
\hline
\end{tabular}

Source: Research Findings

From the above descriptive statistics it is cleared that collateral as well as access to finance plays very important role while borrowing loans. It is also observed that loan from MFIs increased in Khyber Pakhtunkhwa as they support new ventures as well as poor entrepreneurs to establish their business however there are some strict policies of banks which can be achieve to provide a flexible environment for borrowers. Profitability of SMEs can be seen achieved in our province which is very good and initiative process for development of economic growth.

Table 3: Case Processing Summary

\begin{tabular}{llrr}
\hline & & N & \multicolumn{1}{c}{$\%$} \\
\hline Cases & Valid $^{\mathrm{a}}$ & 82 & 100.0 \\
& Excluded $^{\mathrm{a}}$ & 0 & .0 \\
& Total & 82 & 100.0 \\
\hline
\end{tabular}

a. Listwise deletion based on all variables in the procedure. 


\begin{tabular}{cr}
\multicolumn{2}{c}{ Table 4: Reliability Statistics } \\
\hline $\begin{array}{c}\text { Cronbach's } \\
\text { Alpha }\end{array}$ & N of Items \\
\hline .807 & 7 \\
\hline
\end{tabular}

Source: Research Findings

The above reliability statistics shows how much each and every variable is correlated in a group for which .807 shows greater amount of correlation among all taken variables.

\subsection{Regression Analysis}

The impact of MFIs on the growth of SMEs in Khyber Pakhtunkhwa is established by using regression model. The model is as follow

$Y=\alpha_{0}+\beta_{1} X_{1}+\beta_{2} X_{2}+\beta_{3} X_{3}+\beta_{4} X_{4}+\varepsilon$

Where

$\mathrm{Y}=$ Development of Economic Growth (Profitability)

$\mathrm{X} 1=$ Lending to Individuals by MFI's

X2 = Lending of MFI's to Group

$\mathrm{X} 3$ = Collateral towards MFI's

X4 = Accessibility of Credit by MFIs

$\beta=$ Independent variables coefficient

$\alpha_{0}=\mathrm{Y}$ value when all other variables value is zero

$\varepsilon=$ Error term

Table 5: Model Summary

\begin{tabular}{lcrrr}
\hline Model & R & R Square & $\begin{array}{c}\text { Adjusted R } \\
\text { Square }\end{array}$ & $\begin{array}{c}\text { Std. Error of } \\
\text { the Estimate }\end{array}$ \\
\hline 1 & $.789^{\mathrm{a}}$ & .623 & .604 & .643 \\
\hline
\end{tabular}

a. Predictors: (Constant), Collateral, Group Lending by MFIs, Access to Finance, Individual Lending by MFIs

Source: Research Findings

Regression analysis are used to check the relationship between dependent variable profitability of SMEs and independent variables like collateral, access to finance, individual lending and group lending. Correlation value (R) of .789 shows that there is a positive direct relationship between dependable and independent variables from which it is cleared that change occurred in any one of the variable will affect the other values positively or negatively according to the relationship between the variables, while Rsquare of .623 shows $62.3 \%$ of variations in profitability which means that if changes occur in any variable will affect $62.3 \%$ of the other variables. 
Table 6: Coefficients ${ }^{\mathrm{a}}$

\begin{tabular}{|c|c|c|c|c|c|c|}
\hline \multirow[b]{2}{*}{ Model } & & \multicolumn{2}{|c|}{$\begin{array}{c}\text { Unstandardized } \\
\text { Coefficients }\end{array}$} & $\begin{array}{l}\text { Standardized } \\
\text { Coefficients }\end{array}$ & \multirow[b]{2}{*}{$\mathrm{t}$} & \multirow[b]{2}{*}{ Sig. } \\
\hline & & B & Error & Beta & & \\
\hline \multirow[t]{5}{*}{1} & (Constant) & 2.190 & .655 & & 3.342 & .001 \\
\hline & $\begin{array}{l}\text { Accessibility of } \\
\text { Credit by MFI's }\end{array}$ & -.263 & .077 & -.263 & -3.410 & .001 \\
\hline & $\begin{array}{l}\text { Lending to } \\
\text { Individuals by MFI's }\end{array}$ & .147 & .125 & .172 & 1.171 & .245 \\
\hline & $\begin{array}{l}\text { Lending to Group by } \\
\text { MFIs }\end{array}$ & .545 & .124 & .628 & 4.413 & .000 \\
\hline & $\begin{array}{l}\text { Collateral towards } \\
\text { MFI's }\end{array}$ & -.037 & .115 & -.023 & -.320 & .750 \\
\hline
\end{tabular}

a. Dependent Variable: Profitability of SMEs

Source: Research Findings

The above table shows that profitability has positive relationship with individual lending as well as group lending due to the reason that in group lending it is easy for the borrowers to repay as in a group as well as collateral in group lending is equally paid by entrepreneurs while individual lending entrepreneurs faced problems as they manage their business capital all by themselves. Negative relationship is observed with collateral and accessibility of credit with profitability because if accessibility of credit is made difficult for an entrepreneur obviously they are unable to operate in market resulting in the loss as well as the collateral requirement are very high from banks towards entrepreneurs which is a tough step for entrepreneurs to fulfill. A one percent increase in profitability of the SME will increase 14.7 percent, while a one percent increase in profitability of the SME will increase 54.5 of group lending. With a one percent of increase in profitability of the SME will decrease 26.3 percent of access to finance, furthermore with a one percent increase in profitability of the SME a 3.7 percent of collateral will be decrease. The p-value of access to finance and group lending of MFIs shows a high significance result.

Regression model for these variables is

Profitability is equal to 2.190-.263 Accessibility of Credit by MFI's +.147 Lending to Individuals by MFI's +.545 Lending to Group by MFIs -.037 Collateral towards MFI's

\section{Recommendations}

Following are the recommendations for the MFIs.

1. MFIs are required to open a new department as a name of customer care in which they hire competent research scholars performing continuous researches and surveys about problems and demands of customers.

2. Documentation process should be made easy and simple through which it can be easy to access to loans by SMEs and their request cannot be rejected only on collateral basis.

3. Hier Succesion is used in which guarantors are required while availing loan from MFIs which is big issue to have someone else taking risk for their business. This element must be removed from institutions as they already use property as a mortgage. 
4. Electronic Credit Information Bearue (ECIB) has strict rules for repayment of loan and if any SME fails to repay on monthly or quarterly basis they blacklist them as a result they are unable to avail loan again. These rules cannot be eliminated but can be made easy for customers by MFIs.

5. Loan Repayment time is very short arising difficulties for entrepreneurs. Time for repayment of loan should be extended according to the amount of loan availed.

\section{References}

Ahmad, F. \& Salam, A. (2010). An Overview of SME Sector and Examination of Banks Lending to SMEs: A Case Study of Jodia Bazaar - Karachi.

Alhassan, E. A. \& Hoedoafia, M. A. (2016). Entrepreneurial Characteristics and Business Profile of Women Owned Small and Medium Enterprises (SMEs): A Case Study of the Tamale Metropolitan Area. Business Management and Strategy, 7 (1).

Alhassan, E. A., Hoedoafia, M. A., \& Alhassan, E. A. (2016). Determinants of SMEs Growth in the Tamale Metropolis using Logistic Regression. Business and Economic Research, 6 (1).

Alhassan, E. A., Hoedoafia, M. A., Braimah, I. (2016). The Effects of Microcredit on Profitability and the Challenges of Women Owned SMEs: Evidence from Northern Ghana. Journal of Entrepreneurship and Business Innovation , 6 (1).

Anggadwita, G \& Mustafid, Q. (2013). Identification of Factors Influencing the Performance of Small \& Medium Enterprises (SMEs). ScienceDirect, 415-423.

Apogaa, R. R. (2014). Financing in SMEs: Case of the Baltic States. ScienceDirect, 116125.

Awuah, S. B., \& Addaney, M. (2016). The Interactions between Microfinance Institutions and Small and Medium Scale Enterprises in the Sunyani Municipality Of Ghana. Asian Development Policy Review , 4 (2), 51-64.

Bayarcelik, E. B., Tasel, F. \& Apak, S. (2014). A Research on Determining Innovation Factors for SMEs. ScienceDirect, 202-211.

Beck, T., \& Kunt, A. D. (2006, June). Small and Medium-Size Enterprises: Access to Finance as a Growth Constraint. ScienceDirect, 2931-2943.

Boateng, A. (2014). The Role of Microfinace Institutions (MFI's) in Providing Credit Facility to Small and Medium Scale Enterprises (SMEs). nternational Journal of ICT and Management , 2 (2).

Chalu, H. \& Lubawa, G. (2015). Using Financial Statements to Analyze the Effects of Multiple Borrowings on SMEs Financial Performance in Tanzania. International Journal of Research \& Methodology in Social Science , 1 (4).

Du, J. (2017). Bank Competition, Government Intervention and SME Debt Financing. China Finance Review International , 7 (4), 478-492.

Eniolaa, A. A., \& Entebanga, H. (2015). SME Firm Performance-Financial Innovation and Challenges. ScienceDirect, 195, 334-342.

Fall, F. S. (2017). Determinants of Microfinance Institutions' Access to Bank Credit in Senegal. Economics Bulletin, 37 (2), 1327-1338.

Fatoki, O., \& Asah, F. (2011). The Impact of Firm and Entrepreneurial Characteristics on Access to Debt Finance by SMEs in King Williams' Town, South Africa. International Journal of Business and Management , 6 (8). 
Flora, K. A. (2015). The Challenges Confronting Small Scale Businesses in Accessing Microfinance Services from MFIs. International Journal of Academic Research in Business and Social Sciences, 5 (11).

Hamid. K., \& Ullah. A. (2006). Financing the Small and Medium Scale Enterprises in Faisalabad (Pakistan). Journal of Agriculture and Social Sciences , 2 (2), 106-109.

Ibrahim, Z., Abdullah, F., \& Ismail, A. (2016). International Business Competence and Small and Medium Enterprises. ScienceDirect, 393-400.

Jasra, J. M., Khan, M. A., Hunjra, A. I., Rehman, R. A. U. \& Azam, R. I. (2011). Determinants of Business Success of Small and Medium Enterprises.

Johnson Yeboah et al. (2014). The Role of Banks in Financing Small and Medium Scale Enterprises in Ghana- A Case Study of Universal Banks in Sekondi-Takoradi. Journal of Education and Practice, 5.

Karimi, N. E. (2012). The Effect of Credit Financing on Profitability of Small and Medium Sized Enterprises in Nairobi County.

Khan, M. W. J., \& Khalique, M. (2014). Entrepreneurial Approach and Intellectual Capital in Pakistani Manufacturing Pharmaceutical Organizations Introduction. ResearchGate .

Khan, S. (2015). Impact of Sources of Finance on the Growth of SMEs: Evidence from Pakistan. Springer .

Kira, A. R., \& He. Z. (2012). The Impact of Firm Characteristics in Access of Financing by Small and Medium-Sized Enterprises in Tanzania. International Journal of Business and Management , 7 (24).

Kodongo, O., \& Kendi, L. G. (2013). Individual lending versus group lending: An evaluation with kenya's microfinance data. Review of Development Finance, 99-108.

Koskey, D. (2016). Effect of Access to Credit on Profitability of Small and Medium Enterprises in Roysambu Sub-location Nairobi County.

Lang, F., Signore, S., \& Gvetadze, S. (2016). The Role of Cooperative Banks and Smaller Institutions for the Financing of SMEs and Small Midcaps in Europe. European Investment Fund .

Lee, Y. S. (2018). Government guaranteed small business loans and regional growth. Journal of Business Venturing , 70-83.

Maeseneire, W. D., \& Claeys, T. (2006). SMEs, Foreign Direct Investment and financial constrains: The case of Belgium. ScienceDirect , 21 (3), 408-424.

Mbugua, J. K., Mbugua, S, N., Wangoi, M., Ogada, J. O., \& Karuiki, J. N. (2013). Factors Affecting the Growth of Micro and Small Enterprises: A Case of Tailoring and Dressmaking Enterprises in Eldoret. International Journal of Business and Social Science , 4 (5).

Nihtila, M., \& Pasanen, M. (2003). In Search of Factors Affecting SME Performance The Case of Eastern Finland.

Oaya, Z. C. T., \& Mambula I, C. J. (2017). The Impact of SMEs Financing on Business Growth in Nigeria: A Study of Keffi and Mararaba Metropolis. International Journal of Innovation and Economic Development , 3 (2), 44-55.

Omondi, R. I. A., \& Jagango, D. A. (2018). Microfinance Services and Financial Performance of Small and Medium Enterprises of Youth SMEs in Kisumu County, Kenya. International Academic Journal of Economics and Finance , 3 (1), 24-43. 
Otchere, I., Senbet, L., \& Simbanegavi, W. (2017). Financial Sector Development in Africa-An Overview. ScienceDirect, 1-5.

Pirvu, C., Guirca, V. \& Mehedintu, A. (2006). Banking Financing for Romanian SMEsChallenges and Oppurtunities. Munich Personal RePEc Archive (MPRA).

Quartey, P., Turkson, E., Abor, J. Y., \& Iddrisu, A. M. (2017). Financing the growth of SMEs in Africa: What are the constraints to SME financing within ECOWAS? Review of Development Finance, 18-28.

Quaye, I., Abrokwah, E., Sarbah, A., \& Osei, J. W. (2014). Bridging the SME Financing Gap in Ghana: The Role of Microfinance Institutions. Scientific Research , 2 (4), 339353.

Sani, H., Mohd-Khan, S. J., \& Noor, M. S. Z. (2018). Microfinance training and the number of loans received by SMEs. An empirical evidence from emerging economy. BEH-Business and Economic Horizons , 14 (2), 326-341.

Sherazi, S. K., Iqbal, M. Z, Asif, M., Rehman, K. U., \& Shah, S. S. H. (2013). Obstacles to Small and Medium Enterprises in Pakistan. Principal Component Analysis Approach. Middle-East Journal of Scientific Research, 13 (10), 1325-1334.

Sirivanh, T., Sukkabot, S., \& Sateeraroj, M. (2014). The Effect of Entrepreneurial Orientation and Competitive Advantage on SMEs' Growth: A Structural Equation Modeling Study. International Journal of Business and Social Science, 5 (6).

Siyad, A. D. (2013). The Effect of Microfinance Institution Lending on the Growth of Small and Medium Enterprise in Somalia.

Tauseef. S., Lohanu. H. D., \& Khan. S. A. (2015). Effect of Debt Financing on Corporate Financial Performance: Evidence from Textile Firms in Pakistan. Pakistan Business Review.

Tutlani, A. (2016). Borrowers' Participation in Group Borrowing. Turkish Economic Review , 3 (1).

Viverita, Lubis. A. W., Bustaman, Y., \& Riyanti, R. S. (2015). Foreign Bank Entry and Credit Allocation to SMEs: Evidence from ASEAN Countries. ScienceDirect, 10491056.

Zahra, A., Fakhrisadat, N., \& Narges, I. Explaining the Role of Managerial Skills of Entrepreneurship in Business Success. International Journal of Management Sciences , 4 (1), 42-52.

Central Bureau of Statistics. (2011, November 7). Labor Force Situation in Indonesia. Retrieved from https://www.bps.go.id/pressrelease/2011/11/07/949/pada-agustus-2011-tingkat-pengangguran-terbuka-sebesar-6-56-persen.html

European Commission Report. (2005, January 1). Annual Report 2005 on the European Commission's Development Cooperation and External Assistance in 2004.Retrieved from https://ec.europa.eu/europeaid/annual-report-2005-european-commissionsdevelopment-cooperation-and-external-assistance-2004_en

Iqbal, S. (2017, August 24). SME financing rises 27pc. Retrieved from https://www.dawn.com/news/1353516

SMEDA.(2007). SMEDA SME Definition. Retrieved from https://smeda.org/index.php?option=com_fsf \& view=faq \&-catid=3\&faqid $=48$

State Bank of Pakistan. (2007, May 6). Infrastructure, Housing \& SME Finance Department . Retrieved from http://www.sbp.org.pk/smefd/circulars/2016/C2.html 